\title{
The Effectiveness of Project-Based Learning in Instilling University Students' Entrepreneurial Character and Training Science Process Skill
}

\author{
Wiwi Wikanta ${ }^{*}$ \\ ${ }^{1}$ Department of Biology Education, Muhammadiyah University of Surabaya, Surabaya 60113, Indonesia \\ *Corresponding author. Email: wikanta@fkip.um-surabaya.ac.id
}

\begin{abstract}
This study aims to measure the effectiveness of project-based learning models in instilling the entrepreneurial character and training students' science process skills. This research was conducted using a pre-experimental method of one-shot case study design. This research was conducted on 20 students of Biology Education Study Program Faculty of Teacher Training and Education, Muhammadiyah University of Surabaya, Even Semester Academic Year 2018/2019. Research data includes: entrepreneurial character, and science process skills. Data was collected from Several sources, Including: lecture and project implementation processes, scientific papers (project reports), Project products (food, videos, posters), and the presentation of project results. Data were collected using the method of observation and analysed descriptively. the research of data is Categorized into four groups. The results of this study obtained data: entrepreneurial character value of students is 3:34, included in the category of entrenched, and student science process skills value is 2.79 , included in the category of "high". The Conclusions from the results of this study indicate that the projectbased learning models is very effective in instilling the entrepreneurial character and training of science process skills in biology education students.
\end{abstract}

Keywords: student, project-based learning, entrepreneurial character, science process skills

\section{INTRODUCTION}

Entrepreneurial character is a character that required human resources in the face of the 21st century. Entrepreneurship become one of the criteria in determining whether a State forward or backward. A country is said to be developed, if the number of entrepreneurs who are in the country amounts to at least $2 \%$ of its population [1], Some characters WED one should have include: need for Achievement, selfconfidence, proactive, independency/ autonomy and responsibility, Risk Taking propensity, and Experience) [2], According Ciputra [3], a leading entrepreneur in the premises, there are at least three main characteristics of an entrepreneur, namely: (1) Traffic in business opportunities, (2) innovative and creative, and (3) the ability to count the risk.

In addition to the entrepreneurial character, which needs to have human resources in the 21 st century is a life skill. There are three groups of life skills of the 21 st century, namely: (1)learning and innovation skills, (2) Information, Media and Technology Skills, and (3) life and career skills[4][5]. Characters and skills are not formed for granted and not easy, it requires time and effort. Especially the planting of character, according to Agustian [6] required a repetitive training, so that a behaviour becomes a habit and then turns into a character, The formation of character and the most common skills through education. By Karen, the process of education at all levels need to design a model that is possible to embed character and 21 st century skills to students as the future generation.

Project-based learning model or project-based learning $(\mathrm{PjBL})$ is one of the innovative learning models whose characteristics can embed and train a number of characters and skills. Application of the PjBL, both at school and in college already done[1][7][8][9].

The project is a complex task, based on questions or problems that challenge, which involve students in the design, problem solving, decision making, or investigative activities; gives students the opportunity to work relatively independently for long periods of time; and led to a product or a realistic presentation [10], The $\mathrm{PjBL}$ trains students not only the content but also important life skills, played as an adult in a community. Skills are trained include: communication and presentation skills, organization and time management skills, research and inquiry skills, selfassessment and reflection skills, group participation and leadership skills, and critical thinking [11].

Based on the above definition of the project, the implementation of PjBL model in the learning process has a great chance to install entrepreneurship character and science process skills. This study aims to show the effectiveness of the implementation of project-based learning $\log$ models in instilling the entrepreneurial character and practice science process skills of students with a focus on creativity and innovation character of products produced and science process skills. 
(2) science process skills (KPS) collected from several sources, including: (1) the lecture and project implementation, (2) scientific papers (project report), (3) project products (food, videos, posters), (4) the presentation of project results. Data were collected using the observation method with a 4-scale assessment. Data were analysed descriptively using 4 categories of groups, as presented in Table 1.[13]. , Academic Year 2018/2019 of 20 people on Food and Nutritional Biochemistry lecture (BPG). The research data include: (1) the entrepreneurial character (KWU), and

Table 1 Categories Results Entrepreneurial Character and Science Process Skills

\begin{tabular}{|cccc|}
\hline \multirow{2}{*}{ No } & \multirow{2}{*}{ Value Range Results } & \multicolumn{2}{c|}{ Category } \\
\cline { 3 - 4 } & 3.26 to 4.00 & Entrepreneurial Character & Science Process Skills \\
\hline 1 & 2.51 to 3.25 & Entrenched (M) & Very high \\
2 & 1.76 to 2.50 & Start Developing (MB) & High \\
3 & 0 to 1.75 & Starting Visible (MT) & moderate \\
4 & & A Not Seen (BT) & Low \\
\hline
\end{tabular}

\section{RESULTS AND DISCUSSION}

Data from the study include: (1) the data by students, (2)

Value entrepreneurial character, and (3) the value of science process skills. All data are presented successively on Table 2.

Table 2 Results of Student Work

\begin{tabular}{|c|c|c|c|c|}
\hline \multirow{2}{*}{ No. } & \multirow{2}{*}{ Group } & \multicolumn{3}{|c|}{ Title of work } \\
\hline & & papers & Poster & Video \\
\hline 1 & group I & Potato Cheese Ball "BOLTAJU" & $\begin{array}{l}\text { Potato Cheese Ball } \\
\text { "BOLTAJU" }\end{array}$ & manufacture BOLTAJU \\
\hline 2 & group II & $\begin{array}{l}\text { Utilization of carrots as material making jelly rich } \\
\text { vitamin a and economic value }\end{array}$ & $\begin{array}{l}\text { JEDATA: Jelly Daucus } \\
\text { Carota }\end{array}$ & manufacture JEDATA \\
\hline 3 & $\begin{array}{l}\text { group } \\
\text { III }\end{array}$ & $\begin{array}{l}\text { NUGLAU "Nugget Pumpkin and Sweet" as an } \\
\text { Alternative Fast Foods }\end{array}$ & $\begin{array}{l}\text { NUGLAU "nugget } \\
\text { pumpkin and sweet" }\end{array}$ & $\begin{array}{l}\text { Production Method } \\
\text { NUGLAU }\end{array}$ \\
\hline 4 & $\begin{array}{l}\text { group } \\
\text { IV }\end{array}$ & $\begin{array}{l}\text { Utilization of Vegetable Carrots and Beans For } \\
\text { Basic Materials Vegetarian Ball (VegeBall) To } \\
\text { Improve Nutrition in Children }\end{array}$ & $\begin{array}{l}\text { VEGEBALL: Vegetarian } \\
\text { Ball }\end{array}$ & $\begin{array}{l}\text { manufacture } \\
\text { VEGEBALL }\end{array}$ \\
\hline
\end{tabular}

Based on Table 2 above, there are some works that can be produced by students from the problems of food and nutrition. This means that the character of creative and innovation as entrepreneurial character has been demonstrated by the students. The work of students was obtained from a series of lectures Biochemistry of Food and Nutrition by using Project Based Learning Model. Model $\mathrm{PjBL}$ refers to the learning cycle of projects proposed by Colley includes: (1) Orientation to PBS Learning (general or project-specific); (2) identifying and defining a project; (3) planning a project; (4) implementing a project; (5) documenting and reporting project findings; and (6) evaluating and taking action (Colley, 2008; Kamdi, 2013).
The PjBL has an impact on the learning outcomes of cognitive, psychomotor and affective[16], Another study revealed that using $\mathrm{PjBL}$ model to give effect to the planting of character Entrepreneurship, process skill of science and higher order thinking skills (HOTS) although it has not shown satisfactory results [1], Similar results were shown by Sulasari [9] that some of the characters studied entrepreneurship still needs to be improved.

Further research on the character value entrepreneurial in Biology Education Student Guidance and Counselling Department at Muhammadiyah University of Surabaya presented in Table 3.

Table 3 Value Character Enterprise

\begin{tabular}{|c|c|c|c|c|c|c|c|c|}
\hline \multirow[b]{2}{*}{ No } & \multirow[b]{2}{*}{ Group } & \multicolumn{5}{|c|}{ KWU Character } & \multirow[b]{2}{*}{ Sum } & \multirow[b]{2}{*}{ Average } \\
\hline & & 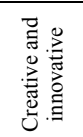 & 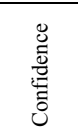 & $\begin{array}{l}\stackrel{\mathscr{u}}{\tilde{z}} \\
\end{array}$ & 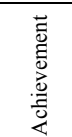 & 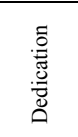 & & \\
\hline 1 & I & 3.58 & 3.20 & 3.20 & 3.60 & 3.40 & 16.98 & 3.40 \\
\hline 2 & II & 3.70 & 3.00 & 3.00 & 3.60 & 3.40 & 16.70 & 3.34 \\
\hline 3 & III & 3.58 & 3.00 & 3.00 & 3.40 & 3.00 & 15.98 & 3.20 \\
\hline 4 & IV & 3.22 & 3.60 & 3.60 & 3.60 & 3.20 & 17.22 & 3.44 \\
\hline & AVERAGE & 3.52 & 3.20 & 3.20 & 3.55 & 3.25 & & 3.34 \\
\hline
\end{tabular}


essential content and skills, students design the process for reaching a solution, requires critical thinking, problem solving, collaboration, and various forms of communication, Provides the opportunity for students to examine the task from different perspectives using a variety of resources, separate the relevant from the irrelevant in formation, and manage the information on they gather, students learn to work Independently and take responsibility when they are asked to make-choices, students regularly reflect on what they're doing, a final product (not necessarily material) is produced and is evaluated for quality, the classroom has an atmosphere that tolerates error and change, the teacher takes on the role of a facilitator rather than a leader [5].

The results of this study prove that the PjBL model can install entrepreneurial character during the learning process. Visually Value entrepreneurial character Students can be seen in Figure 1. predetermined solution, creates a need to know of the

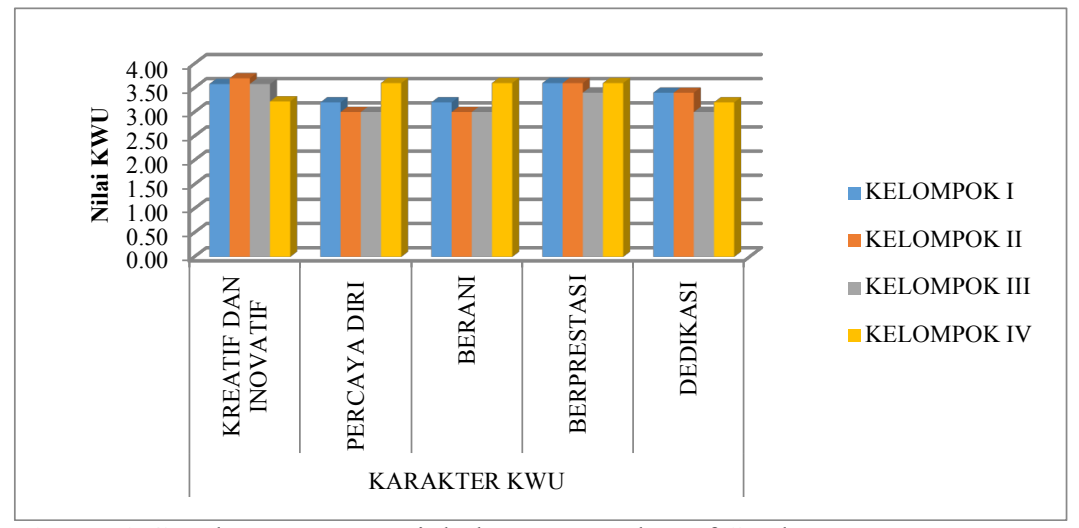

Figure 1 Graph entrepreneurial character Value of Students

On the other hand, the application of research results to the PjBL model of science process skill has been obtained from the data presented in Table 4.

Table 4 Values of Science Process Skills

\begin{tabular}{|c|c|c|c|c|c|c|c|c|c|}
\hline \multirow[b]{2}{*}{ No } & \multirow[b]{2}{*}{ Group } & \multicolumn{6}{|c|}{ Science Process Skills } & \multirow[b]{2}{*}{ Total } & \multirow[b]{2}{*}{ Average } \\
\hline & & 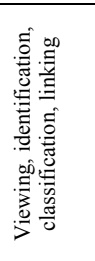 & 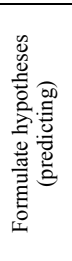 & 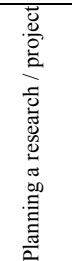 & 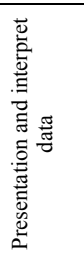 & 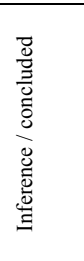 & 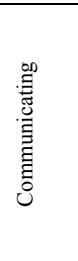 & & \\
\hline 1 & I & 1.00 & 2.00 & 3.00 & 2.00 & 2.00 & 3.00 & 13 & 2.17 \\
\hline 2 & II & 3.00 & 4.00 & 3.00 & 2.00 & 2.00 & 4.00 & 18 & 3.00 \\
\hline 3 & III & 3.00 & 4.00 & 4.00 & 4.00 & 4.00 & 4.00 & 23 & 3.83 \\
\hline 4 & IV & 2.00 & 2.00 & 3.00 & 2.00 & 1.00 & 3.00 & 13 & 2.17 \\
\hline & AVERAGE & 2.25 & 3.00 & 3.25 & 2.50 & 2.25 & 3.50 & & 2.79 \\
\hline
\end{tabular}

Based on data achievement in Table 4 above, the average value amounted to 2.79 Science Process Skills. This value excludes the category of "High". These results together with the results of previous studies with a value of 3.01[1]. In visually Science Process Skills value of students are presented in Figure 2. 


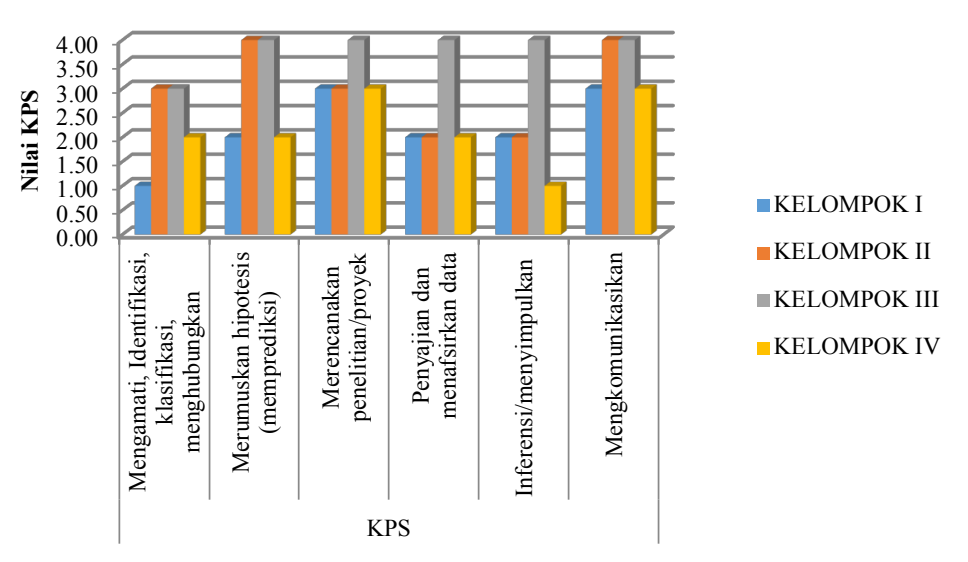

Figure 2 Graph Science Process Skills of Students.

Actually, the PjBL model has great potential for training skills, because the PjBL model practiced by either having the following essential elements[14]: (1) A rich, complex driving question that is relevant to students' lives, (2) Production of artefacts, (3) Student-centered learning, (3) Collaboration, (4) Accountability, (5) Authentic use of technology, (6) Interdisciplinary and cross-disciplinary inquiry, (7) Extended time frame, and (8) Valid and reliable performance-based assessment. The characteristics of this PPA model has relevance to the characteristics of the competencies required of learners as a result of learning in the 21 st Century [17], In addition, the characteristics of the PjBL Model is a series of science process skills, namely: (1)observing or observed, including: calculate, measure, classify, find the relationship of space / time; (2) make a hypothesis; (3) planned studies / experiments; (4) controls the variable; (5) interpret or interpret data; (6) the conclusions as provisional (inference); (7) forecast (predicting); (8) applies (apply); and (9) communicates[18], Although, the results of this study have shown no evidence that the PjBL Model BPG lectures can embed entrepreneurship character and train Science Process Skills on students. However, there are disadvantages that need to be considered in the application of this PPA model. The weakness of the application of this PjBL model, is among others: (1) Most of the problems of the "real world" that is integral with discipline problems, it is advisable to teach by training and facilitate learners in dealing with problems. (2) Requires a lot of time to be done to solve the problem, (3) Requires cost quite a lot, (4) Many of the instructors who are comfortable with traditional classroom, where instructors play a major role in the classroom, and (5) Number of equipment must be provided, (6) Learners who have a weakness in the experiment and collection of information will have trouble, (7) There is a possibility of learners who are less active in the work of the group, and (8) When the topic is given to each group is different, it is feared learners cannot understand the topic overall.[19], Successful implementation of the PjBL model in the learning process, both at school and in college depends on the ability to design learning teacher or professor, so as to minimize the weaknesses of the PjBL model [20]

\section{CONCLUSION}

Based on the above, the results of this research can be concluded that the project-based learning model is effective in instilling the entrepreneurial character (characters KWU) and practice science process skills. The results of this study can be used as a model of learning in preparing human resources in Indonesia face the 21 st century, while welcoming Industry 4.0 Revolution.

\section{ACKNOWLEDGMENT}

The end of this article, researcher expresses many thanks to the Chancellor, Dean of Guidance and Counselling, and Head of Department of Biology Education who have supported this research, either in the form of material in the form of financial support, and moral support. Moreover, thanks go to colleagues' professors, students, and laboratory environment Biology Education Study Program which has helped in data collection and input materials so that these articles can be compiled.

\section{REFERENCES}

[1] W. Wikanta and Y. Gayatri, "Pembelajaran berbasis proyek dalam menanamkan karakter kewirausahaan, Kketerampilan proses sains, dan keterampilan tingkat tinggi mahasiswa," JIP, vol. 23, no. 2, pp. 171-175, 2017.

[2] A. Al Jufri, G. Anggadwita, and M. K. Putri, "Pengaruh Karakteristik Entrepreneur Terhadap Kesuksesan Usaha Kuliner Di Kabupaten Bandung ( Studi Kasus : Usaha Kuliner Kecamatan Bojongsoang ) 
[12] Sugiyono, Metode Penelitian Kuantitatif, Kualitatif dan R\&D, Cetakan ke. Bandung: Alfabet, 2014.

[13] N. Asyiah and L. Sunanto, "Optimalisasi Penerapan Pendidikan Karakter,” Mimb. Sekol. Dasar, vol. 1, pp. 161-167, 2014.

sebuah Ilmu. Jakarta: Penerbit Erlangga, 2015.

[4] B. Trilling and C. Fadel, 21St Century Skills: Learning For Life in Our Times. San Francisco: JosseyBass, 2009.

[5] P21 Framework for 21st century learning, "Framework for 21st century learning," P21 Partnersh. 21st Century Learn., p. 2, 2009.

[6] A. G. Agustian, Rahasia Sukses Membangun Kecerdasan Emosi dan Spiritual: ESQ Emosional Spiritual Quotient Berdasarkan 6 Rukun Iman dan 5 Rukun Islam. Jakarta: Arga, 2001.

[7] R. D. Lisminingsih, "Meningkatkan Karakter Siswa Sekolah Dasar di Dalam Pengelolaan Energi melalui Pembelajaran Berbasis Proyek Berbantuan Komputer.," in Seminar dan Workshop Nasional Biologi/IPA dan Pembelajarannya, 2014, pp. 439-346.

[8] Y. Sudarya, "Pengembangan Project-Based Learning dalam Mata Kuliah Evaluasi Pembelajaran di PGSD Bumi Siliwangi UPI," J. Pendidik. Dasar, vol. 10, pp. 2006-2009, 2008.

[9] A. Sulasari, "Pengembangan Metode Pembelajaran Kewirausahaan Berbasis Proyek untuk meningkatkan Karakter Wirausaha Mahasiswa di Politeknik Negeri Malang," J. Akuntansi, Bisnis dan Manaj., vol. 23, no. 1, pp. 1-15, 2016.

[10] B. Pearlman and J. W. Thomas, "Review Of Research On Project-Based Learning," The Autodesk Foundation, 2000.

[11] J. Stivers, "Project-Based Learning," in ProjectBased Learning, Brandon Goodman, 2010, p. 8.
[14] K. Colley, "Project-Based Science Intruction: A Primer An Introduction and Learning Cycle for Implementing Project-Based Science," Sci. Teach. NSTA's Peer-reviewed Sch. J. Second. Sci. Teach., vol. 75 , no. 8 , pp. 23-28, 2008.

[15] W. Kamdi, "Bab II: Pembelajaran berbasis proyek," in Panduan Pengembangan Model Pembelajaran Berbasis Kompetensi, 2013.

[16] A. Gangga, J. Jama, and Ridwan, "Penerapan Model Pembelajaran Project Based Learning Dalam Peningkatan Motivasi Dan Hasil Belajar," J. Pendidik. Teknol. dan Kejuru., vol. 2, no. 3, 2013.

[17] E. Baker, B. Trygg, P. Otto, M. Tudor, and L. Ferguson, Project-Based Learning Model Relevant Learning Relevant Learning for the 21 st Century, no. December. Pacific Education Institute, 2011.

[18] C. Semiawan, A. F. Tangyong, S. Belen, Y. Matahelemual, and W. Suseloardjo, Pendekatan Keterampilan proses: Bagaimana mengaktifkan siswa dalam belajar. Jakarta: PT Gramedia, 1989.

[19] M. A. Titu, "Penerapan Model Pembelajaran Project Based Learning (Pjbl) Untuk Meningkatkan Kreativitas Siswa Pada Materi Konsep Masalah Ekonomi,”J. VARIDIKA, p. 11, 2015.

[20] M. Fikriyah, Indrawati, and A. A. Gani, "Model Pembelajaran Berbasis Proyek (Project Based Learning) Disertai Media Audio-Visual Dalam Pembelajaran Fisika Di Sman 4 Jember," J. Pembelajaran Fis., vol. 4, no. 2, pp. 181-186, 2015. 